\title{
Insecurity, Citizenship, and Globalization: The Multiple Faces of State Protection*
}

\author{
DANIEL BÉLAND \\ University of Calgary
}

\begin{abstract}
Adopting a long-term historical perspective, this article examines the growing complexity and the internal tensions of state protection in Western Europe and North America. Beginning with Charles Tilly's theory about state building and organized crime, the discussion follows with a critical analysis of $T$. H. Marshall's article on citizenship. Arguing that state protection has become far more multifaceted than what Marshall's triadic model suggests, the article shows how this protection frequently transcends the logic of individual rights while increasing the reliance of citizens on the modern state. The last section formulates a critique of the idea formulated by theorists like Manuel Castells that globalization favors a rapid decline of state power. Yet, state protection may not necessarily grow indefinitely, and tax cuts, for example, the ones recently enacted in the United States, could seriously jeopardize a state's capacity to raise revenues and effectively fight older and newer forms of insecurity.
\end{abstract}

The terrorist attacks of September 11, 2001, have increased the general concerns regarding the protective duties of the modern state as they exacerbate the tension between the respect of individual rights and the imperative of national security. Considering the scope of the apparent terrorist threat, the state is perceived more than ever as the main source of security and military protection. Still, excessive state power is widely considered a possible menace to individual rights and freedoms; the preservation of comprehensive legal and constitutional limitations of state power is viewed as a necessary safeguard in democratic societies. The debate concerning the desirable scope - and limits - of security enforcement in the United States and other Western societies that has emerged since the events of September 11 exemplifies the enduring ambiguity of state protection and the fears related to excessive concentration of state power. While this present-day debate splits public intellectuals, policymakers, and interest groups, a discussion of the origin and the development of the protective faces of the modern state in Western Europe and North America proves useful. ${ }^{1}$ Such a consideration could shed new light on the current debate regarding the desirable scope - and the internal tensions - of state protection.

Adopting a long-term historical perspective, here I examine the internal tensions and the growing complexity of state protection in Western Europe and North

\footnotetext{
*I am grateful to Angela Kempf, Abdolali Rezaei, Pierre Rosanvallon, Bruno Théret, Charles Tilly, and three anonymous reviewers for their comments. I also thank all the participants in my graduate political sociology seminar at the University of Calgary (fall 2002 and winter 2004). Address correspondence to: Daniel Béland, Department of Sociology, University of Calgary, 2500 University Drive NW, Calgary, Alberta, Canada T2N 1N4. E-mail: dbeland@ucalgary.ca

${ }^{1}$ Without negating the specificity of each state, this theoretical account aims to identify cross-national patterns of state development.
} 
America. ${ }^{2}$ I reconstruct the genealogy of the modern state's protective missions, from physical security to social policy and protection against terrorist acts and environmental hazards. ${ }^{3}$ To integrate scattered pieces of knowledge about state intervention found in the literature, I draw on the work of social theorists such as Ulrich Beck, T. H. Marshall, Pierre Rosanvallon, and Charles Tilly. In the first section, I introduce key concepts such as state protection and political participation before discussing Tilly's argument on the analogy between state-making and organized crime. I then show that a systematic analysis of state protection must move beyond the issue of physical security per se to take into account other faces of state protection that have emerged since the 17 th century. To do so, I discuss T. H. Marshall's widely debated genealogy of citizenship before framing a more accurate long-term vision of state protection's historical development. As I argue, state protection cannot be reduced to formal citizenship rights, and it has become far more multifaceted than what Marshall's triadic model suggests. To illustrate this claim, in the last section of the article, I briefly discuss the emergence of new social, technological, and terrorist risks that favor further extensions of state protection. Although they are loosely related and not always effective, all these forms of protection have increased civil society's reliance on the state. Lastly, I formulate a critique of the idea that the process of economic globalization has favored a rapid decline of national states. This discussion focuses on Manuel Castells's account of the so-called network society. While recognizing the enduring protective powers of national states in Western Europe and North America, however, I also discuss the current "contradictions of state protection" and the lasting relationship between protection and fiscal extraction. As I argue, state protection does not necessarily grow indefinitely, and tax cuts - for example, the ones recently enacted in the United States - could seriously jeopardize a state's capacity to raise revenues and effectively fight older and newer forms of collective insecurity.

\section{STATE-MAKING AS A PROTECTION RACKET?}

The state fulfills four major tasks in modern societies: (1) protecting citizens against internal and external threats while granting formal rights; (2) regulating the economic and social life through public education, law-making, and monetary policy; ${ }^{4}$ (3) redistributing material and symbolic resources; and (4) extracting fiscal resources to finance the first three tasks. These four tasks are interrelated. For example, economic regulation is often linked to income redistribution and the protection of social rights. Once this interdependence is acknowledged, this typology provides scholars with a basic framework to identify the complex set of state interventions that have a structuring impact on civil society. Because the level and the institutional configuration of political participation work to shape these four types of state intervention, I start

\footnotetext{
${ }^{2}$ Throughout this article, the word "state" is used in the European sense: a set of institutions at the center of a geographically bounded territory that has the power to make and enforce the rules that govern civil society - the social world as it is distinct from state institutions (Hall and Ikenberry 1989:1-2). In the United States, this set of institutions is generally referred to as "government."

${ }^{3}$ In this article, the term "genealogy" only means "diachronic development," and it does not refer to Michel Foucault's theoretical framework.

${ }^{4}$ Framing general cultural, economic, and social objectives for civil society (agenda-setting) is related to this general task.
} 
from the perspective that social and political mobilization stemming from civil society largely affects the configuration of these types of intervention. These four tasks change over time and from place to place. Moreover, each task has "multiple faces" that have emerged at different historical moments. Loosely articulated together, these strata of state intervention accumulate over time, exacerbating fiscal pressures and internal tensions as well as social and political feedback effects. In the remainder of this text, I focus on the historical development of state protection, which is related to social and economic transformations that shape civil society and impact state-making. Not an entirely coherent set of interventions, the "multiple faces of state protection" all increase the reliance of citizens on the modern state while creating tensions like the one between national security and individual rights.

An interesting starting point for a theoretical discussion about the origin of modern state protection is Tilly's (1985) provocative "War Making and State Making as Organized Crime," a text aimed at exploring the emergence of the state in feudal and early modern Europe. ${ }^{5}$ Here, war-making and state-making are closely related, and there is an analogy between these two processes and what "we call organized crime .... Banditry, piracy, gangland rivalry, policing, and war-making belong to the same continuum" (Tilly 1985:170). To support this surprising analogy, he starts from the ambiguous meaning of the term "protection" in the common language: "In contemporary American parlance, the word 'protection' sounds two contrasting tones. One is comforting, the other ominous. With one tone, 'protection' calls up images of the shelter against danger provided by a powerful friend, a large insurance policy, or a sturdy roof. With the other, it evokes the racket in which a local strong man forces merchants to pay tribute in order to avoid damage-damage the strong man himself threatens to deliver" (Tilly 1985:170). Because states frequently stimulate or even fabricate violent threats to justify their existence and reinforce their power, state-making is analogous to extortion, the only difference being that state power is perceived as legitimate because many authorities recognize it as such. ${ }^{6}$

Without going as far as reducing emerging state power to pure violence, Tilly (1985:172) recognizes the centrality of force and war-marking in the process of state-building and the development of state protection in Western Europe. In medieval and early modern Europe, state-making was mostly the product of conquests and the elimination of local rivals. This military expansion was about what the economic historian Frederic Lane calls "the business of selling protection... whether people want it or not" (Tilly 1985:175). The construction of the modern state can be understood as a process where populations have to pay the fiscal (taxes) and human (military service) price of protection they do not always seek against threats that state-builders sometimes fabricate.

According to Tilly (1985:181), agents of the state carry four different activities within the state-building process: war-making (eliminating external rivals), statemaking (eliminating their internal rivals), protection (eliminating the enemies of their clients), and extraction (acquiring the means to pursue the three activities mentioned above). These activities can take different forms, but they all "depend on

\footnotetext{
${ }^{5}$ For more general considerations concerning the emergence of the modern state, see Hall and Ikenberry (1989), Poggi (1978), and Strayer (1970).

${ }^{6}$ Here, Tilly draws heavily on Stinchcombe's (1968) realistic vision of authority and legitimacy. Although stimulating, this vision seems rather narrow, especially when applied to contemporary democratic societies (Habermas 1975). On the analogy between state-making and protection rackets, see also Volkov (2000).
} 
the state's tendency to monopolize the concentrated means of coercion" (Tilly 1985:181). Over the long run, they favor the creation of stable and relatively centralized organizations that give shape to the modern state's sovereignty while gradually eliminating - or absorbing - competing forms of protection and extraction such as city-states. ${ }^{7}$ Although forms of popular resistance can lead to concessions such as guarantees of rights and representative institutions, the early modern state can still be understood as the product of violent conquest and imposed protection/extraction (Tilly 1985:183). Indeed, before the 20th century, "any state that failed to put considerable effort in war-making was likely to disappear" (Tilly 1985:184). Without sustained war-making efforts, especially the creation of a national army financed through a centralized taxation system, state-making could rarely lead to the establishment of an enduring and stable territorial order. In this context, protecting the population against real or fabricated threats of violence is the best way to justify taxation, that is, the extraction of resources necessary to the reproduction - and the expansion - of war-making and state institutions.

Tilly's analysis provides scholars with stimulating insights on the emergence of the modern state. Beyond the existence of significant national differences, his provocative analogy between state-making and organized crime illustrates how the modern state emerged as a set of organizations involved in the business of eliminating rivals while "selling protection." Unfortunately, in his attempt to explore the affinity between state-making and war-making, Tilly seems to reduce the relationship between the rising modern state and society to protection and extraction, leaving aside two other key missions of the state: regulation and redistribution. ${ }^{8}$ Although these two dimensions of the state-society nexus tend to grow only after the establishment of a stable territorial order, their role in state-making seems essential. Even when focusing on state protection, we have to recognize the diversity and the complexity of state interventions (Rosanvallon 1990). Moreover, in his 1985 chapter, Tilly does not analyze the multiple faces of state protection, which cannot be limited to policing and military security. ${ }^{9}$ To explore the history of state protection, it is useful to turn to T. H. Marshall's classical genealogy of modern citizenship. The analysis of his historical typology will lead to a critical discussion concerning the multiple faces of state protection. The main objective will be to move beyond Marshall's triadic model to explore the multifaceted nature of modern state protection while criticizing liberal vision that focuses almost exclusively on the recognition of individual rights. ${ }^{10}$

\section{CITIZENSHIP AND THE MULTIPLE FACES OF STATE PROTECTION}

Written immediately after World War II, T. H. Marshall's “Citizenship and Social Class" is an attempt to reconstruct the genealogy of modern citizenship. According to Marshall, the emergence of modern citizenship is a response to the tension between

\footnotetext{
${ }^{7}$ For an alternative view on the emergence of the modern state that stresses the role of economic factors, see Spruyt (1994).

${ }^{8}$ During and after the medieval era, the state performed regulatory tasks related to the gradual institution of integrated legal systems. It also redistributed economic and symbolic resources among social classes.

${ }^{9}$ This is probably related to the fact that, in his 1985 chapter, Tilly focuses mainly on the medieval era, during which war-making represented the most central form of state protection. This author gives more attention to the "multiple faces of state protection" in other publications (e.g., Tilly 1990).

${ }^{10}$ Some elements of the following discussion concerning the work of T. H. Marshall were first sketched in Béland and Hansen (1998).
} 
social inequality and the imperative of "basic human equality" derived from "full membership" in a political community. Therefore, the most fundamental issue at stake concerning the development of citizenship is the contradiction between the existence of socioeconomic inequality and the need for recognizing each individual as a full member of the political community. Grounded in the liberal tradition, Marshall's analysis portrays modern citizenship as the personal ownership of rights granted by the state. His vision of citizenship concerns the extension of state protection and redistribution through the recognition and differentiation of rights. ${ }^{11}$ The emergence of modern citizenship concerns the recognition of rights that fall into three categories that emerge chronologically: civil, political, and social rights. ${ }^{12}$

Marshall starts from the perspective that civil rights represent the foundation of modern citizenship, but also the ground from which capitalism grows. Indeed, what he calls civil citizenship "is composed of the rights necessary for individual freedomliberty of the person, freedom of speech, thought and faith, the right to own property and to conclude valid contracts, and the right to justice" (Marshall 1964:71). Emerging during the 18th century, the idea of economic freedom would be accepted as idiomatic by the beginning of the following century, notably with the repeal of the Elizabethan statutes (Marshall 1964:76). The generalization of civil rights - at the center of the liberal crusade-leads to the establishment of a "market society" (Polanyi 1957). ${ }^{13}$ Protection of individual rights, such as private property, stimulates the emergence of a new system of economic regulation in which the state is expected to perform only a small number of basic tasks like policing and military protection. According to Marshall, modern social classes are the product of this capitalist system, which could not exist without the protection of individual freedom and property rights. The egalitarian logic of state protection paradoxically favors the advent of a system of economic regulation that creates disruptive forms of socioeconomic inequality.

The history of the second category of rights "is different both in time and in character" (Marshall 1964:77). Emerging after the recognition/protection of most civil rights, political citizenship is not about the creation of new rights but "the granting of old rights to new sections of the population" (Marshall 1964:77). The gradual recognition of universal suffrage, the pivotal modern political right, provides ground to this claim. When women gained the right to vote, the basis of political rights shifted "from economic substance to personal status" (Marshall 1964:78). As political rights became an integral part of egalitarian citizenship, private property and class position were no longer the formal ground for political participation. If civil rights constitute the liberal component of modern citizenship, the enlargement of political rights created a democratic order that formally extended political participation beyond class boundaries.

For Marshall, the recognition of social rights is a response to the tensions between capitalist inequality and the imperative of equality derived from full political membership. Through the development of social services and income-related programs, the state protects individuals against economic risks, such as unemployment, while reducing the scope of inequality in the capitalist society.

\footnotetext{
${ }^{11}$ During the medieval era, rights "were wound into a single thread. The rights were blended because the institutions were amalgamated" (Marshall 1964:72). According to Marshall, there was "no principle of the equality of citizens to set against the principle of the inequality of classes" (Marshall 1964:72).

${ }^{12}$ Marshall draws on the British historical experience to illustrate his claims, but "Citizenship and Social Class" is frequently referred to as a general analysis of modern citizenship per se.

${ }^{13}$ In his article, Marshall actually refers to Karl Polanyi's book The Great Transformation.
} 
There is a general enrichment of the concrete substance of civilized life, a general reduction of risk and insecurity, an equalization between the more and the less fortunate at all levels - between the healthy and the sick, the employed and the unemployed, the old and the active, the bachelor and the father of a large family. Equalization is not so much between classes as between individuals within a population which is now treated for this purpose as though it were one class. Equality of status is more important than equality of income. (Marshall $1964: 102)^{14}$

Writing in the context of the labor reforms of the second half of the 1940s, Marshall emphasizes social policy's redistributive role without directly discussing the role of social insurance, a protective instrument aimed at fighting economic risks. Established by the state but frequently managed by employers and professional groups, social insurance schemes have been instrumental in protecting workers against economic risks like unemployment and poverty related to old age. According to the French sociologist Robert Castel, social insurance and other social programs have created a "wage society" in which employment, traditionally perceived as a deprived condition, finally represents a genuine source of security for workers. Alongside the liberal security based on private property (propriété-sécurité), a new form of rights-based economic security (sécurité-droit) derived from state protection emerged during the 20th century (Castel 2003a). Social citizenship is about income redistribution as well as the development of a new form of protection against social risks granted by the state. ${ }^{15}$ Interestingly, this form of citizenship often takes the shape of state-granted individual rights, which is consistent with the liberal logic of legal protection. Despite the fact that many liberal thinkers opposed the development of social citizenship in the name of individual freedom and the respect of private property, the modern welfare state could also be considered an extension of the liberal state aimed at protecting its citizens through the process of rights-granting (Rosanvallon 1981). To summarize Marshall's argument while drawing on this last remark, social citizenship represents both the extension and the transformation of a liberal logic of protection aimed at reducing the level of insecurity and inequality created by the capitalist system, which largely stems from the recognition of civil rights at the center of the liberal tradition. The strengthening of extraction powers through the establishment of new taxes made the recognition - and the reproduction - of modern social rights possible.

More than 50 years after its publication, T. H. Marshall's article still provides scholars with a useful starting point for the study of modern state protection development. It takes economic redistribution and political participation into account while exploring key contradictions of modern citizenship. In spite of these qualities, "Citizenship and Social Class" has been rightly criticized since its publication, and a considerable revisionist literature arises from Marshall's analysis. From J. M. Barbaret to Thomas Janoski, numerous authors have challenged or amended his historical model (e.g., Janoski 1998; Bulmer and Rees 1996; Barbalet 1988).

\footnotetext{
${ }^{14}$ Such an analysis reflects the universalistic logic of the British "Beveridgian model." In Bismarckian welfare states such as France and Germany, professional-based social insurance schemes have favored the emergence of fragmented social rights stratified among occupational lines (Baldwin 1990). In the United States and other countries, the heavy reliance on private benefits has led to another form of social rights fragmentation (Esping-Andersen 1990; Hacker 2002).

${ }^{15}$ According to Ewald (1986), the emergence of the welfare state at the end of the 19th century is linked to the construction of social risks and the reconfiguration of personal responsibility.
} 
While acknowledging the scope of this literature, the following paragraphs formulate not more than a few brief remarks concerning the limits of Marshall's article. ${ }^{16}$

Perhaps, the most obvious problem with Marshall's analysis of modern citizenship is that it does not emphasize the political struggles and the bargaining processes that could explain "where rights come from" (Tilly 1999; Moore 1966). For example, references to women's struggles and gender inequality are rare in "Citizenship and Social Class" (Leister 1990); colonialism and ethnic domination are not even discussed. Another problem with Marshall's genealogy of citizenship is that it is far too linear and not rooted in a comparative perspective that underlines key differences between national historical trajectories. As noted by Dahrendorf (1996), for example, social rights do not always emerge after the establishment of political citizenship (1996). The German experience under the rule of Otto von Bismarck supports this claim (Mann 1987). ${ }^{17}$

Regarding the analysis of state protection per se, Marshall's model is also problematic. First, it reduces protection to the recognition of rights, which is consistent with the liberal tradition but not with sound sociological analysis. State protection in contemporary societies does not always take the shape of formal rights. Second, such a model does not recognize the diversity of national experiences and institutional settings in the field of social policy (Esping-Andersen 1990). Third, Marshall's trilogy of rights excessively reduces citizenship and state protection to a triadic logic. Although this typology is useful, a more subtle understanding of the interaction between the modern state and civil society is needed.

Pierre Rosanvallon's discussion of the political construction of public health (hygiène publique) in France is an excellent starting point to transcend some of the limitations of Marshall's theory. For Rosanvallon, the emergence of public health during the second half of the 19th century is distinct from the emergence of modern social rights. While the welfare state protects individual workers and redistributes income, the "public health state" (Etat hygiéniste) protects society as a whole by developing vaccination programs and reducing the scope of industrial problems at the origin of contamination and poisoning. Developed as a consequence of Pasteur's discoveries, public health is related to the modern idea of social solidarity, which states that society is not a mere collection of "separated individuals" but an interdependent whole in need of state protection and regulation. Within this social order, the state has the mission to regulate social and economic life to protect the population against epidemic contamination (Rosanvallon 1990:128-35). Located beyond the strict separation of the public and the private spheres, the "public health state" gradually emerged in France and in other industrial countries as a specific face of state protection that has little to do with the liberal logic of individual protection and citizenship rights at the center of Marshall's analysis. ${ }^{18}$ The advent of modern public health during the second half of the 19th century shows how multidimensional modern state protection is. Beyond policing, national security, and the recognition of citizenship rights, the state tends to protect civil society against an increasing number of socioeconomic risks.

\footnotetext{
${ }^{16}$ For a survey of the debates surrounding the work of T. H. Marshall, see Kymlicka and Norman (1995) and Turner (1993).

${ }^{17}$ Some authors have also argued that Marshall's model is too centered on the national state and that it is illsuited to the understanding of current political issues such as European integration (Bulmer and Rees 1996).

${ }^{18}$ For a long-term perspective on the history of public health, see Porter (1999).
} 


\section{GLOBALIZATION AND EMERGING FORMS OF PROTECTION}

Since the publication of Marshall's article, new forms of state protection have been developed while older ones have faced fresh challenges. Confronting pressures from social movements and business interests alike, contemporary West European and North American states have simultaneously multiplied their protective interventions and struggled to eliminate public deficits. Although not exhaustive, the following section briefly introduces three significant new (and not so new) "faces of state protection": environmental protection, cultural rights, and the so-called war on terrorism. Loosely related, these forms of state protection have all contributed to an increase in societal reliance on the state. This analysis naturally leads to a discussion concerning the present vulnerability of established forms of state protection in the context of socioeconomic globalization.

Protecting citizens and the natural environment against chemical and nuclear hazards has emerged as a new and central mission of the state in advanced industrial societies. This development is a response to the "hazardous side effects" of economic modernization that exacerbate environmental risks: "In the modernization process, more and more destructive forces are also being unleashed, forces before which the human imagination stands in awe" (Beck 1998a:20). As illustrated by the 1986 Tchernobyl nuclear catastrophe and the propagation of the mad cow disease (BSE), these new environmental risks are both difficult to predict and global in scope. Facing pressures from ecologist groups and the general population, European and North American states have enacted measures to prevent such accidents and to react quickly in case of an emergency. Moreover, efforts have been made to reduce the pollution that increases health and environmental risks. This new model of state intervention takes the shape of domestic legislation and international agreements (Franklin 1998). Generally opposed by business interest groups in the name of economic efficiency and economic freedom, states' environmental protection and regulation follow a logic similar to the development of modern public health during the second half of the 19 th century. Related to the scientific construction of global risks and grounded in the idea of interdependence, environmental protection transcends the liberal logic of individual rights, despite the attempt of some lawyers and animal rights advocates to reduce environmental protection issues to rights (Zimmerman et al. 2000). Still, new environmental risks seem even less predictable than the epidemic phenomena discovered by Pasteur. State efforts to cope with these new risks seem problematic, because it is hard to identify forces at the origin of environmental catastrophes: "Risk societies are characterized by the paradox of more and more environmental degradation, perceived and possible, and an extension of environmental law and regulation. Yet at the same time no individual or institution seems to be held specifically accountable for anything" (Beck 1998a:18). Moreover, the supranational nature of these threats further calls into question the power of the national state to protect the population against environmental catastrophes and health risks related to pollution, which are not randomly distributed (Beck 1998b). ${ }^{19}$ Despite the growing role of international treaties and organizations, the national state still constitutes the main source of environmental protection and regulation in Western Europe and North America.

Terrorism is another "global threat" that exacerbates doubts concerning the ability of national states to adequately protect citizens. The recent terrorist attacks in New

\footnotetext{
${ }^{19}$ The case of nuclear waste provides ground to this claim (McCutcheon 2002).
} 
York City and Washington, DC, have shown how difficult it is for intelligence services to detect and neutralize terrorist threats. ${ }^{20}$ As mentioned earlier, the "war on terrorism" also heightens the tensions between the imperative of national security and individual rights and freedoms. These tensions are related to the fact that the current crusade against terrorism is not an entirely new form of state protection but the reinforcement of the security apparatuses at the foundation of the state-building process. The strengthening of national security is widely perceived as a threat to basic civil and constitutional rights of citizenship created during the long-term bargaining process between state officials and civil social movements (Tilly 1999). On behalf of national security, citizen rights meant to protect individuals from excessive state power seem more fragile than before the recent terrorist wave. Moreover, U.S. President George W. Bush's discourse following September 11 about so-called rogue states and the "axis of evil" (Iraq, Iran, and North Korea) illustrates Tilly's idea that state officials can exaggerate of - or at least exploit- the scope potential threats to promote their interests at home and abroad. From this perspective, the President seems to overdramatize the international situation by depicting these countries as manifesting an immediate menace for the rest of the world (e.g., Bush 2002). The misleading presidential rhetoric about Iraqi "weapons of mass destruction" and the supposed link between al Qaeda and the Hussein regime that justified the 2003 invasion of Iraq illustrates this ideological logic (Dreyfuss and Vest 2004). ${ }^{21}$ As stated by Tilly (1985), the state can protect civil society against threats that state officials themselves can exaggerate or even fabricate. Therefore, the so-called war on terrorism is not an entirely original form of protection but, in some ways, is a new expression of the original state-building logic.

Undeniably, the "war on terrorism" potentially threatens the ability of national states both to protect citizens and to respect individual rights. The debate over the "USA Patriot Act" provides ground to this claim. Signed by President George W. Bush on October 26, 2001, this legislation "enhanced the executive branch's powers to conduct surveillance, search for money-laundering, share intelligence with criminal prosecutors, and charge suspected terrorists with crimes" (Goldstein 2003:A01). Meant to neutralize potential terrorist threats, this new law has been widely criticized by human rights advocates in the United States and abroad (Goldstein 2003; Hentoff 2003). If the outcome of the "war on terrorism" is still unknown, it seems probable that the potential conflict between civil rights and the imperative of national security will remain at the center of the public agenda in Western Europe and North America in the years to come. The tension between civil rights and policing is especially striking in the United States where "zero tolerance" policies enacted to fight delinquency and illegal drugs have implicitly targeted ethnic and racial minorities while increasing the prison population. ${ }^{22}$ The maintenance of such a large prison population and the increase in military spending associated with the "war on terrorism" (Milbank and Allen 2003) could divert resources from other areas of state protection like social policy and environmental protection.

If environmental regulations and national security protect citizens against global threats, "cultural citizenship" entails the extended recognition of particular identities

\footnotetext{
${ }^{20} \mathrm{Far}$ from being a recent invention, terrorism constitutes only one possible form of political terror among others. According to Tilly (2004), we must also acknowledge that the actual number of international terrorist attacks declined significantly between the mid-1980s and the early 2000s.

${ }^{21}$ The author thanks Roland Simon for his insight about this issue.

${ }^{22}$ Following the American example, West European countries such as France and the United Kingdom have recently implemented "zero tolerance" policies (Castel 2003b; Wacquant 1999).
} 
in the public arena. Related to the ideas of diversity and multiculturalism, this emerging form of citizenship actually concerns the integration of minorities through the allocation of individual rights derived from ethnic, racial, and gender-based identities. This process is related to the growing political role of courts in Western democracies and to what is often referred to as "identity politics" and "rights talk" (Glendon 1991). In some countries, pressures from Aboriginal movements have been instrumental in the development of a fragmented vision of citizenship in which the state claims both to protect and to empower cultural minorities. In Canada, the development of "multiculturalism" as an official state policy since the 1970s has been at the center of this new protective mission of the state: guaranteeing the rights and the cultural survival of minorities (Bourques, Duchastel, and Pineault 1999). Even in countries where the idea of multiculturalism has not been transformed into a set of formal programs to preserve diversity and protect endangered "cultural species," multiculturalism is gaining ground as a prominent political discourse in most Western democracies, including the traditionally "universalistic" France (Schnapper 2002). Yet, it is unsure if multiculturalism as a new variant of state protection and regulation will have an enduring impact on civil society beyond the rhetoric of diversity and the granting of symbolic rights. ${ }^{23}$ What seems essential here is that, in many countries, the logic of "cultural citizenship" favors the multiplication of group-based rights that are distinct from the Universalistic logic of liberal citizenship. If modern state protection cannot be reduced to expansion of rights, it is hard to deny the current multiplication of rights linked to the recognition of fragmented identities.

If new forms of state protection have emerged since the postwar era, current economic and social transformations call into question public policies enacted during earlier historical stages. This phenomenon exacerbates internal contradictions of modern citizenship already described in Marshall's "Citizenship and Social Class." Furthermore, such a phenomenon shows that, while institutionalized state protection can erode over time, it can also prove resilient to massive neoliberal attacks. The example of social protection provides ground to this claim.

Since the end of the 1970s, the decline of Keynesianism and the related rise of neoliberalism have apparently undermined the economic and ideological foundations of the welfare state, especially in the Anglo-American world. Based on the idea that markets are generally more efficient than states in distributing resources and regulating the economy, neoliberalism promotes the application of market solutions to public policy issues (Campbell and Pedersen 2001). If "old liberalism" opposed dirigisme and socialism in the name of market efficiency and "possessive individualism" (MacPherson 1962), contemporary neoliberalism found a massive target in the welfare state. ${ }^{24}$ Generally depicted as an economic burden and a source of "welfare dependency," social spending must be reduced to lessen the tax burden and favor economic prosperity. Neoliberalism also promotes personal responsibility as an alternative to "welfare dependency" while expressing skepticism toward most forms of governmental interventions (Somers and Block forthcoming). This leads neoliberal economists and politicians to promote the development of market-based protections like private insurance, which could reduce the need for direct state intervention. ${ }^{25}$

\footnotetext{
${ }^{23}$ In Canada, multiculturalism has been accused of exacerbating fragmentation within civil society (Bissoondath 2002).

${ }^{24}$ This is already apparent in Hayek's (1944) Road to Serfdom.

${ }^{25}$ The irony of the neoliberal project is that, through indirect and low-profile fiscal measures, the state should encourage the development of private protections imagined as an alternative to direct public policy (Hacker 2002).
} 
In the United States, right-wing libertarianism represents the most radical form of neoliberalism (Nash 1996).

Although "coordinated market economy" still represents a viable alternative to the Anglo-American model associated with neoliberalism and remains dominant in many West European countries, ${ }^{26}$ the growing influence of market ideas since the 1970 s has directly contributed to the emergence of the "new politics of the welfare state" (Pierson 1994). This politics is characterized by the enactment of fiscal cutbacks and cost-control measures, but also by the instauration of work requirements (workfare) and personal savings schemes meant to increase the level of self-reliance and personal savings (Quadagno 1999; Cox 1998). Despite the domination of neoliberalism and pressures from business interest groups, the "new politics of the welfare state" has not led to a dismantlement of modern welfare states, which are characterized by a high level of resilience (Pierson 1994). Large social programs create broad constituencies and vested interests that force even the most conservative politicians to avoid open revolutions in the field of social protection. Facing huge political risks, politicians pursue blame-avoidance strategies to implement cutbacks without losing too much political capital (Pierson 1994; Weaver 1986). In spite of that dominant institutional logic, significant policy change has been witnessed in some North American and West European countries since the beginning of the 1980s (e.g., Cox 2001; Myles and Pierson 1997). As demonstrated by the 1996 U.S. welfare reform, the state can significantly alter the content of social rights and, as a consequence, transform the very nature of the welfare state (Somers and Block forthcoming).

As this example shows, state protection is an historical construction that may be altered by policy changes related to long-term economic, social, and political mutations. $^{27}$ Yet, in the field of social policy, it seems impossible to evoke genuine convergence between national social policy systems. Profound international differences remain both in terms of social expenditure levels and institutional settings (Swank 2002; Esping-Andersen 2001, 1999). Beyond these enduring cross-national variations, West European and North American states still play a crucial role in redistributing income and protecting citizens and workers against economic insecurity.

In the current debate on the fate of the modern state, it is common to argue that the prevalent economic and social transformations subsumed under the umbrella concept of globalization do not only complicate the state's protective tasks but favor the rapid decline of state power. ${ }^{28}$ In a recent book, for example, Hardt and Negri (2000) claim that the world is witnessing the emergence of a global capitalist "Empire" in which national states occupy a less central position than before. ${ }^{29}$

Sociologist Manuel Castells is among the scholars arguing that the modern state is facing a rapid decline. According to him, the planetary expansion of information

\footnotetext{
${ }^{26}$ Present in countries such as Germany, the Netherlands, and Sweden, "coordinated market economy" refers to an integrated system where economic actors such as employers and labor unions coordinate strategies that do not derive exclusively from market relations. Although neoliberalism has been influential in these countries, "coordinated market economy" has proven surprisingly resilient in the last two decades (Hall and Soskice 2001).

${ }^{27}$ One should also note that changing risk patterns related to demographic aging and transformations in the family structure can undermine the efficiency - and even the relevance — of existing forms of protection and, in some contexts, justify the enactment of measures especially designed to address emerging socioeconomic needs (Esping-Andersen 1999).

${ }^{28}$ Here, the concept of globalization refers to the reduction of geographic constraints on economic, social, and political relations. Although this concept is relatively recent, globalization itself is everything but a new phenomenon. Yet, the last few decades have witnessed an intensification of the long-term processes tied to globalization (Giddens 1990).

${ }^{29}$ In this brief article, it is impossible to review the growing literature on globalization and the state. This has been accomplished elsewhere (e.g., Berger 2000; Spruyt 2002).
} 
networks is at odds with national state institutions and hierarchies: "Networks dissolve centers, they disorganize hierarchy, and make materially impossible the exercise of hierarchical power without processing instructions in the network, according to the network's morphological rules. Thus, contemporary information networks of capital, production, trade, science, communication, human rights, and crime bypass the national state, which, by and large, has stopped being a sovereign entity" (Castells 2000:19). Rooted in a form of technological determinism, this vision seems to oversimplify the impact of economic and social globalization on state institutions and protection. Not passive victims of the globalization process, West European and North American policymakers have generally played the game of economic integration to gain electoral power and push for their own political agenda at home. Promising more prosperity as a consequence, these actors stress the fact that economic integration could benefit their country and even stimulate welfare state development and coordination (Théret 2001). ${ }^{30}$ The enactment of the North American Free Trade Agreement (NAFTA) and, more importantly, the creation of the European Union (EU) are the most spectacular outcomes of the "integration strategy" initiated by state actors.

Although European integration has favored a relative decline of national sovereignty in policy areas like immigration and economic regulation, only time will tell if the EU can radically increase - and concentrate - its protective power at the expense of member states. ${ }^{31}$ According to Bruno Théret, the development of a federal European welfare state is necessary to justify the EU as a genuine political order that has a concrete and positive meaning for the populations living under its rule. From his perspective, the EU should multiply its social interventions to reinforce its political and symbolic integration while respecting the federal autonomy of the member states (Théret 2002). Over the next few decades, the expansion of European citizenship and institutions could favor the multiplication of supranational state protections distinct from, but not necessarily in contradiction with, existing national forms of intervention. Beyond this possible territorial reconfiguration of state power and protection at the supranational level, national states still represent the main source of economic, environmental, social, and military protection in Western Europe and also in North America.

The above discussions about terrorism, environmental risks, and social policy show that socioeconomic integration creates new constraints for policymakers while altering the nature and the scope of modern state protection. Yet, the enduring-and even increasing - role of the state and the relative strength of its power in West European and North American societies seem patent, despite durable international variations in terms of tax (OECD 2001) and public spending levels (Tanzi and Schuknecht 2000). In a way, the recent terrorist attacks have only reinforced the state's legitimacy as the main source of security in advanced capitalist societies. ${ }^{32}$ Considering what has been said above, as well as the long-term trends concerning public spending (Table 1), the idea of a dramatic decline of state power related to economic globalization is excessive. The insightful analysis of Canadian economist John Helliwell (2002) and the

\footnotetext{
${ }^{30}$ In Canada, for example, the Liberal government in power since 1993 has promoted economic integration (NAFTA) while stressing the need to preserve and even improve the country's welfare state, which has been reframed as a competitive tool oriented toward the production (and reproduction) of human capital (Théret 2001).

${ }^{31}$ For a general discussion concerning the construction of the EU, see Wallace and Wallace (2000).

${ }^{32}$ Yet, as Castells would argue, the state has now to fight elusive terrorist networks that require the development of reinforced, global intelligence networks.
} 
Table 1. Government Real Expenditure, 1937-1995 (\% of GDP)

\begin{tabular}{lccccc}
\hline & 1937 & 1960 & 1980 & 1990 & 1995 \\
\hline Canada & 10.1 & 13.4 & 19.2 & 19.8 & 19.6 \\
France & 15.0 & 14.2 & 18.1 & 18.0 & 19.3 \\
Italy & - & 12.0 & 14.7 & 17.4 & 16.3 \\
Germany & 21.0 & 13.4 & 20.2 & 18.4 & 19.5 \\
Spain & 10.7 & 8.3 & 12.5 & 15.5 & 16.6 \\
Sweden & 10.4 & 16.0 & 29.3 & 27.4 & 25.8 \\
United Kingdom & 11.7 & 16.4 & 21.6 & 20.6 & 21.4 \\
United States & 12.9 & 19.4 & 18.7 & 18.9 & 16.2 \\
\hline
\end{tabular}

Source: Tanzi and Schuknecht (2000:25).

contributions to the recent edited volume titled The Nation-State in Question (Paul, Ikenberry, and Hall 2003) strengthen the claim that the state can still implement policies that strongly impact the life of its citizens. The state remains the foremost agent of economic, social, and military protection in West European and North American societies.

Although it is crucial to acknowledge this reality, we should keep in mind two precautionary remarks. First, what has been said about West European and North American societies does not necessarily apply to other regions of the world. In many former socialist countries, for example, the departure from economic planning, widespread neoliberal reforms, and the expansion of the informal sector have at least temporarily reduced the state's capacity to extract fiscal resources and protect citizens against many of the above-mentioned threats. As in the past, declining or insufficient state protection and growing personal insecurity tend to stimulate the development of alternative providers of protection such as militias and criminal organizations (Volkov 2002; Varese 2001; Stanley 1996; Gambetta 1993). ${ }^{33}$ Second, even in West European and North American societies, state protection may not expand-or even maintain itself-indefinitely. Although there is little evidence that economic globalization per se has drastically reduced state capacity in these societies, domestic political actors themselves could shrink the state's fiscal resources through the enactment of widespread tax breaks that, in the long run, could seriously reduce the state's capacity to protect citizens effectively. Because protection capacity is tied to extraction powers, and because tax cuts are politically difficult to overturn, "fiscal crises" stemming from deep tax breaks represent a potential menace against state protection that could legitimize new budget cuts in social and environmental programs as well as the multiplication of alternative, market-based protection providers at the center of the neoliberal project. This situation could increase the level of social inequality, as market-based protection and the tax incentives that stimulate its expansion tend to disproportionately benefit wealthier citizens and their families (Hacker 2002). The United States is probably the advanced industrial country in which the emergence of a large-scale "fiscal crisis" is most likely to have a negative impact on state protection. The massive federal tax cuts enacted in 2001 and 2003 have already favored the return of mammoth federal

\footnotetext{
${ }^{33}$ Market providers of protection have also grown in recent years, even in countries such as the United States, which have not witnessed a radical decline in state capacity (Benson 1997). The influence of neoliberalism at least partly explains this trend.
} 
deficits (Galbraith 2003). And, even if these tax cuts were enacted as temporary measures, pressure is strong to make them permanent (Beach 2004). ${ }^{34}$ In the future, these tax cuts could thus justify bolder retrenchment efforts and reduce the federal state's capacity to effectively fight older and newer threats-from economic insecurity and environmental hazards to international terrorism. Considering that many of the 50 U.S. states also face formidable fiscal pressures (Johnson and Ribeiro 2003), the situation of the United States poses a paradox. In the world's most powerful state, elected officials promoting the economic interests of narrow-and affluent - constituencies $^{35}$ have significantly reduced the capacity of the state to raise revenues while increasing military spending and breeding popular fears about terrorism. Consequently, the United States faces a deepening contradiction between declining extraction powers and rising protection needs. ${ }^{36}$ The tension between the respect of individual rights and national security imperatives further complicates the landscape of contemporary U.S. state protection.

\section{CONCLUSION}

As these remarks about the United States show, the future of state protection remains uncertain. Employing a long-term historical perspective, I underlined the increasing complexity and the internal tensions of state protection in Western Europe and North America. Using Charles Tilly's theory about state-building and organized crime as a starting point, I formulated a critical analysis of T. H. Marshall's article on citizenship, arguing that state protection has become far more multifaceted than what Marshall's triadic model suggests. I also demonstrated that the relationship between state protection and civil society should not be reduced to the recognition of individual rights. If liberalism has played a significant ideological role in framing modern state protection, environmental and social risks necessitate responses that are often independent from the logic of rights. Moreover, the enforcement of "national security" at the origin of modern state-building still clashes with the most fundamental civil rights. In this context, the relationship between state and civil society is more ambiguous than ever. To protect a fragmented civil society, the state must extract fiscal resources that are sometimes used to finance questionable or perfectible environmental and social measures or, even worse, shield citizens against fabricated or overdramatized threats. While facing significant challenges, state capacity and state protection have not sharply declined in the context of economic globalization, at least not in Western Europe and North America. Yet, because both globalization and state-building represent changing, long-term historical processes, and because state capacity is based upon fluctuating extraction powers, we cannot assume that the level of state protection would indefinitely increase or even remain constant.

Beyond narrow specialization, state protection could become a central issue in social theory and political sociology. While intensive research has been conducted in subfields like social policy and environmental policy, it is appropriate to integrate

\footnotetext{
${ }^{34}$ During the 2004 presidential campaign, President Bush maintained that the tax cuts should become permanent. His Democratic opponent, Senator John Kerry, vowed to repeal the tax cuts for people earning over \$200,000 a year while supporting further tax cuts for the middle class (Connolly and Weisman 2004).

${ }^{35}$ According to Hacker and Pierson (2003), the size, the structure, and the redistribution of the massive 2001 federal tax cut were totally at odds with median-voter preferences. This legislation essentially served the economic interests of the wealthy.

${ }^{36}$ To a certain extent, this situation is reminiscent of the one prevailing during President Reagan's first mandate. At the time, Congress simultaneously raised military spending and cut taxes. In a context of economic recession, the federal deficit soared, legitimizing retrenchment (Edsall 1984).
} 
scattered pieces of theoretical and empirical knowledge to provide a better understanding of state-making and state protection at the era of socioeconomic globalization. Without such an attempt, our knowledge of state protection would remain too fragmented to inform current debates about globalization, individual rights, and the fate of the modern state adequately. This exploratory article shows both the interest of this synthetic approach and, more importantly, the multifaceted nature of - and the growing reliance of civil society on-state protection.

\section{REFERENCES}

Baldwin, P. 1990. The Politics of Social Solidarity: Class Bases of the European Welfare State 1875-1975. Cambridge: Cambridge University Press.

Barbalet, J. M. 1988. Citizenship: Rights, Struggle and Class Inequality. Milton Keynes: Open University Press. Beach, W. W. 2004. Make the Temporary Tax Cuts Permanent Tax Reductions. Heritage Foundation: WebMemo \#403 (January 22). Retrieved from http://www.heritage.org/Research/Taxes/wm403.cfm.

Beck, U. 1998a. "Politics of Risk Society." Pp. 9-22 in The Politics of Risk Society, edited by F. Jane. London: Polity Press/IPPR. .1998b. Risk Society. London: Sage Publications.

Béland, D. and R. Hansen. 1998. "La question de la citoyenneté sociale au Royaume-Uni: vers une réflexion européenne?” Droit Social November:918-26.

Benson, B. L. 1997. "Crime Control Through Private Enterprise." Independent Review 2(3):341-71.

Berger, S. 2000. "Globalization and Politics." Annual Review of Political Science 3:43-62.

Bissoondath, N. 2002. Selling Illusions: The Cult of Multiculturalism in Canada, 2nd ed. Toronto: Penguin Books.

Bourques, G., J. Ducheastel, and E. Pineault. 1999. "L'incorporation de la citoyenneté." Sociologie et Sociétés XXXI(2):41-64.

Bulmer, A. and A. M. Reeds, eds. 1996. Citizenship Today: The Contemporary Relevance of T. H. Marshall. London: UCL Press.

Bush, G. W. 2002. The President's State of the Union Address. Washington: Office of the Press Secretary. (January 29).

Campbell, J. and O. K. Pedersen, eds. 2001. The Rise of Neoliberalism and Institutional Analysis. Princeton: Princeton University Press.

Castel, R. [1995] 2003a. From Manual Workers to Wage Laborers: Transformation of the Social Question. New Brunswick: Transaction Publishers.

2003b. L'insécurité sociale: Qu'est-ce qu'être protégé? Paris: Le Seuil.

Castells, M. 2000. "Material for an Exploratory Theory of the Network Society." British Journal of Sociology. 51(1):5-24.

Connolly, C. and J. Weisman. 2004. "The Choice for Voters: Health Care or Tax Cuts. Policy Costs Crowd Out Other Initiatives." Washington Post June 28:A01.

Cox, R. H. 1998. "The Consequences of Welfare Reform: How Conceptions of Social Rights are Changing." Journal of Social Policy 27(1):1-16.

. 2001. "The Social Construction of an Imperative: Why Welfare Reform Happened in Denmark and the Netherlands but Not in Germany." World Politics 53:463-98.

Dahrendorf, R. 1996. "Citizenship and Social Capital." In Citizenship Today, edited by M. Bulmer and A. M. Rees. London: UCL Press.

Dreyfuss, R. and J. Vest. 2004. "The Lie Factory.” Mother Jones January/February:34-41.

Edsall, T. 1984. The New Politics of Inequality. New York: W.W. Norton.

Esping-Andersen, G. 1990. The Three Worlds of Welfare Capitalism. Princeton: Princeton University Press. . 1999. Social Foundations of Postindustrial Economies. Oxford: Oxford University Press.

Ewald, F. 1986. L'etat-providence. Paris: Grasset.

Franklin, J., ed. 1998. The Politics of Risk Society. London: Polity Press/IPPR.

Galbraith, J. K. 2003. "Bush Tax Cuts Will Do a Number on Us." Newsday May 24.

Gambetta, D. 1993. The Sicilian Mafia: The Business of Private Protection. Cambridge: Harvard University Press.

Giddens, A. 1990. The Consequences of Modernity. Stanford: Stanford University Press.

Glendon, M. A. 1991. Rights Talk: The Impoverishment of Political Discourse. New York: Free Press. 
Goldstein, A. 2003. "Fierce Fight Over Secrecy, Scope of Law Amid Rights Debate, Law Cloaks Data on its Impact." Washington Post September 8:A01.

Habermas, J. 1975. Legitimation Crisis. Boston: Beacon Press.

Hacker, J. S. 2002. The Divided Welfare State: The Battle Over Public and Private Social Benefits in the United States. Cambridge: Cambridge University Press.

Hacker, J. S. and P. Pierson. 2003. Abandoning the Middle: the Revealing Case of the Bush Tax Cuts. Paper presented at the annual meeting of the American Political Science Association, Philadelphia Marriott Hotel, Philadelphia, PA (August 27).

Hall, J. A. and J. Ikenberry. 1989. The State. Minneapolis: University of Minnesota Press.

Hall, P. A. and D. Soskice, eds. 2001. Varieties of Capitalism: The Institutional Foundations of Comparative Advantage. Oxford: Oxford University Press.

Hardt, M. and A. Negri. 2000. Empire. Cambridge: Harvard University Press.

Hayek, F. 1944. The Road to Serfdom. London: Routledge \& Kegan Paul.

Helliwell, J. F. 2002. Globalization and Well-Being. Vancouver: University of British Columbia Press.

Hentoff, N. 2003. "Vanishing Liberties: Where's the Press?" Village Voice April 11. Retrieved from http:// www.villagevoice.com/issues/0316/hentoff.php.

Janoski, T. 1998. Citizenship and Civil Society: A Framework of Rights and Obligations in Liberal, Traditional and Social Democratic Regimes. Cambridge: Cambridge University Press.

Johnson, N. and R. Ribeiro. 2003. Severe State Fiscal Crisis May Be Worsening. Washington: Center on Budget and Policy Priorities (May 9). Retrieved from http://www.cbpp.org/5-903sfp2.htm.

Kymlicka, W. and W. Norman. 1985. "Return of the Citizen: A Survey of Recent Work on Citizenship Theory.” Pp. 283-322 in Theorizing Citizenship, edited by R. Beiner. Albany: State University of New York Press.

Leister, R. 1990. "Women, Economic Dependency, and Citizenship.” Journal of Social Policy 19(4):445-65.

MacPherson, C. B. 1962. The Political Theory of Possessive Individualism: Hobbes to Locke. Oxford: Clarendon Press.

Mann, M. 1987. "Ruling Class Strategies and Citizenship.” Sociology 21(3):339-54.

Marshall, T. H. 1964. "Citizenship and Social Class." Pp. 65-122 in Class, Citizenship and Development, edited by T. H. Marshall. Garden City, NY: Doubleday.

McCutcheon, C. 2002. Nuclear Reactions: The Politics of Opening a Radioactive Waste Disposal Site. Albuquerque: University of New Mexico Press.

Milbank, D. and M. Allen. 2003. "Bush to Double Iraq Spending: President Seeks \$87 Billion More for Postwar Effort." Washington Post September 8:A01.

Moore, B. Jr. 1966. Social Origins of Dictatorship and Democracy: Lord and Peasant in the Making of the Modern World. Boston: Beacon Press.

Myles, J. and P. Pierson. 1997. "Friedman's Revenge: The Reform of 'Liberal' Welfare States in Canada and the United States." Politics and Society 25(4):443-72.

Nash, G. H. [1976] 1996. The Conservative Intellectual Movement in America Since 1945. Wilmington: Intercollegiate Studies Institute.

OECD. 2001. "Challenges for Tax Policy in OECD Countries." OECD Economic Outlook 69, June.

Paul, T. V., G. J. Ikenberry, and J. Hall, eds. 2003. The Nation-State in Question. Princeton: Princeton University Press.

Pierson, P. 1994. Dismantling the Welfare State? Reagan, Thatcher, and the Politics of Retrenchment. Oxford: Cambridge University Press.

Poggi, G. 1978. The Development of the Modern State: A Sociological Introduction. Stanford: Stanford University Press.

Polanyi, K. [1944] 1957. The Great Transformation: The Political and Economic Origins of Our Time. Boston: Beacon Press.

Porter, D. 1999. Health, Civilization and the State: A History of Public Health from Ancient to Modern Times. New York: Routledge.

Quadagno, J. 1999. "Creating a Capital Investment Welfare State.” American Sociological Review 64(1):1-10.

Rosanvallon, P. 1981. La crise de l'etat-providence. Paris: Le Seuil. 1990. L'etat en france de 1789 à nos jours. Paris: Le Seuil.

Schnapper, D. 2002. La démocratie providentielle. Essai sur l'égalité contemporaine. Paris: Gallimard.

Somers, M. and F. Block. Forthcoming. "From Poverty to Perversity: Ideational Embeddedness, the Rise and Reprise of Market Liberalism." American Sociological Review.

Spruyt, H. 1994. The Sovereign State and its Competitors: An Analysis of Systems Change. Princeton: Princeton University Press. 
2002. "The Origins, Development, and Possible Decline of the Modern State." Annual Review of Political Science 5:127-49.

Stanley, W. 1996. The Protection Racket State. Elite Politics, Military Extortion, and Civil War in El Salvador. Philadelphia: Temple University Press.

Stinchcombe, A. L. 1968. Constructing Social Theories. New York: Harcourt, Brace and World.

Strayer, J. R. 1970. On the Medieval Origins of the Modern State. Princeton: Princeton University Press.

Swank, D. 2002. Global Capital, Political Institutions, and Policy Change in Developed Welfare States. Cambridge: Cambridge University Press.

Tanzi, V. and L. Schuknecht. 2000. Public Spending in the 20th Century: A Global Perspective. Cambridge: Cambridge University Press.

Théret, B. 2001. "La solidarité sociale dans le pacte fédéral canadien. Histoire d'une crise et de son dénouement." Critique Internationale April:145-60. 2002. Protection sociale et fédéralisme. L'Europe dans le miroir de l'Amérique du nord. Bruxelles, P.I.E.-Peter Lang/Montréal: Presses de l'Université de Montréal.

Tilly, C. 1985. "War Making and State Making as Organized Crime." Pp. 169-91 in Bringing the State Back In, edited by P. B. Evans, D. Rueschmeyer, and T. Skocpol. Cambridge: Cambridge University Press. 1990. Coercion, Capital, and European States, AD 990-1992. Oxford: Blackwell. 1999. “Where Do Rights Come From?” Pp. 55-72 in Democracy, Revolution and History, edited by

T. Skocpol. Cornell: Cornell University Press. . 2004. "Terror, Terrorism, Terrorists." Sociological Theory 22(1):5-13.

Turner, B. S., ed. 1993. Citizenship and Social Theory. London: Sage.

Varese, F. 2001. The Russian Mafia: Private Protection in a New Market Economy. Oxford: Oxford University Press.

Volkov, V. 2000. "The Political Economy of Protection Rackets in the Past and the Present." Social Research 67(3):709-44. . 2002. Violent Entrepreneurs: The Use of Force in the Making of Russian Capitalism. Ithaca: Cornell University Press.

Wacquant, L. 1999. Les prisons de la misère. Paris: Raisons d'agir/Du Seuil.

Wallace, H. and W. Wallace, eds. 2000. Policy-Making in the European Union, 4th ed. Oxford: Oxford University Press.

Weaver, R. K. 1986. "The Politics of Blame Avoidance.” Journal of Public Policy 4(6):371-86.

Zimmerman, M. E., K. J. Warren, J. B. Callicott, and J. G. Sessions, eds. 2000. Environmental Philosophy: From Animal Rights to Radical Ecology, 3rd ed. Upper Saddle River, NJ: Prentice Hall. 